\title{
DA COMPOSIÇÃO À PRODUÇÃO TEXTUAL: ONDE SE SITUA O ENEM?
}

\section{FROM COMPOSITION TO TEXT PRODUCTION: WHERE DOES ENEM FIT?}

Emanuel Cordeiro da Silva (UFRPE) ${ }^{1}$

\section{RESUMO}

Este trabalho objetiva situar o Exame Nacional do Ensino Médio (ENEM) no conjunto das transformações sofridas pelo ensino da escrita no Brasil. A partir da realização de uma breve incursão histórica acerca do ensino do português e de sua escrita, bem como com base nas relações traçadas entre a perspectiva da produção textual, as recomendações dos PCNEM e as concepções assumidas pelo ENEM, as visões de língua e de texto subjacentes ao sistema de avaliação do exame são observadas, e ele é situado no processo das mudanças sofridas pelo ensino da escrita na educação básica brasileira. É verificado que a ruptura existente no sistema avaliativo, permeado por duas concepções divergentes de língua e de texto, leva o próprio sistema a incorrer numa contradição. Embora o ENEM, de maneira articulada com os PCNEM, assuma como princípio a indissociabilidade entre conhecimento e cidadania, buscando, na relevância prática e social, a valorização do conhecimento, o exame ainda preza por uma escrita alheia à sua relevância prática e social, indo de encontro às recomendações dos PCNEM.

PALAVRAS-CHAVE: escrita; avaliação; ENEM.

1 Doutor em Letras pela Universidade Federal de Pernambuco. Email: emanuel_cord@yahoo. com.br 


\section{ABSTRACT}

This paper aims to place the ENEM (Exame Nacional do Ensino Médio, High School National Exam) in the set of transformations by which the teaching writing passed in Brazil. First, we will show a little about the history of Portuguese teaching and writing teaching in Portuguese as well as discuss relations between text production perspective and the conceptions that ENEM has about education and writing teaching. Thereafter, referring to the evaluation method of the exam, we will discuss the underlying language and text views to place it in the historical process of the writing teaching in the Brazilian education. We verified that the exam contains two divergent conceptions of language and text. This fact implies a contradiction. In an articulation with PCNEM (Parâmetros Curriculares Nacionais do Ensino Médio, High School National Curricular Parameters), despite ENEM supports the practical and social relevance of knowledge, it still emphasizes a writing practice disconnected from its social relevance, contradicting the recommendations of PCNEM.

KEYWORDS: writing; evaluation; ENEM.

\section{INTRODUÇÃO}

Este artigo objetiva situar o Exame Nacional do Ensino Médio (ENEM) no conjunto das transformações sofridas pelo ensino da escrita no Brasil. Para tanto, haja vista a histórica vinculação entre o ensino da língua e da sua escrita, é, primeiramente, apresentado um breve panorama do caminho por ambos percorrido desde os primeiros séculos da colonização até os dias atuais. Em seguida, é realizada uma discussão acerca da vigente concepção de ensino da escrita como produção textual. Para tal concepção convergem as visões de língua e de texto recomendadas pelos Parâmetros Curriculares Nacionais do Ensino Médio (PCNEM) e, por meio dela, é que o ENEM se propõe a realizar a avaliação da competência textual dos alunos egressos da educação básica.

A partir da pequena incursão histórica realizada e com base nas relações traçadas entre a perspectiva da produção textual, as recomendações 
dos PCNEM e as concepções assumidas pelo ENEM, é que as visões

: de língua e de texto subjacentes ao sistema de avaliação do exame são observadas, e ele é situado no processo das mudanças sofridas pelo ensino da escrita na educação básica brasileira.

\section{Um pouco da história do ensino da escrita no brasil}

No Brasil, somente a partir de meados do século XVIII, começa a se formar um contexto favorável à entrada do português no rol das disciplinas do currículo escolar. Até então, a língua portuguesa não gozava do prestígio social nem do arcabouço de conhecimento necessários à escolarização de seu conteúdo. Nos primeiros séculos da colonização, a língua latina e a chamada língua geral concorriam socialmente com a portuguesa. A primeira estava na base de todo o ensino dos padres jesuítas, e a segunda servia-lhes à catequese dos povos indígenas. Ademais, apesar das gramáticas e das cartilhas de ortografia surgidas entre os séculos XVI e XVII - por exemplo: a primeira gramática do português de Fernão de Oliveira data de 1536 -, faltava ainda à língua portuguesa consolidarse como área de conhecimento. Como bem destaca Soares (in BAGNO, 2002, p. 159),

não havia nem condições internas ao próprio conteúdo que ainda não se configurava como área de conhecimento, a que faltava uma tradição como área de estudos - nem condições externas a ele - seu uso apenas secundário no intercurso verbal, a precariedade de seu estatuto escrito, na incipiente sociedade brasileira, enfim, seu pouco valor como bem cultural - para que o português adquirisse estatuto de disciplina curricular.

Na segunda metade do século XVIII, com vistas ao fortalecimento do domínio de Portugal sobre suas colônias, as reformas do Marquês de Pombal impõem a obrigatoriedade do uso da língua da metrópole na colônia brasileira. Em consequência de tal medida, ocorre uma valorização da língua portuguesa frente às concorrentes. Daí então, tanto o latim quanto a língua geral começam paulatinamente a ceder espaço 
ao português. Some-se a isso também o fato de que o surgimento da Impressão Régia do Rio de Janeiro, em 1808, possibilita a publicação de : várias gramáticas, contribuindo para a consolidação dos estudos da língua portuguesa enquanto área de conhecimento. Diante dessa conjuntura, torna-se possível ao português a aquisição do estatuto de disciplina curricular nas últimas décadas do século XIX.

Todavia, a sua entrada no rol das disciplinas escolares não resulta em mudanças metodológicas significativas. As transformações sociais ocorridas implicam novos valores do português perante a sociedade e, consequentemente, perante a escola, mas não lhe alteram o modelo de ensino. Até o início do século XX, permanece o estudo fragmentado em retórica, poética e gramática; só que, agora, sob o rótulo único de português. Permanece também a primazia do ensino da gramática portuguesa, introduzido desde as reformas pombalinas. Soares (op. cit., p. 165) afirma que

Embora a disciplina curricular se denominasse português, persistiram embutidas nela as disciplinas anteriores, até mesmo com individualidade e autonomia, o que se comprova pela convivência na escola, nas cinco primeiras décadas do século XX, de dois diferentes e independentes manuais didáticos: as gramáticas e as coletâneas de textos.

Sendo assim, o ensino da escrita, que sempre ocorreu dentro dos limites da divisão entre retórica, poética e gramática, continua a darse da mesma forma. Persiste a crença de que o estudo da gramática da língua e o estudo dos textos de escritores consagrados asseguram o domínio da competência da escrita. O "trabalho" com a elaboração de textos permanece limitado à redação dentro dos parâmetros gramaticais e estilísticos prestigiados pela classe dominante. Se a inserção do português como disciplina no currículo escolar é recente, o ensino sistemático da escrita decorrente dela é mais recente ainda. Beth Marcuschi (in RANGEL; ROJO, 2010, p. 67) diz que

o século XX dá continuidade ao encaminhamento pedagógico que já vinha sendo adotado nas últimas décadas 
do século XIX. Assim, na primeira metade do século passado, a escritura em sala de aula era solicitada na forma de uma "composição livre", de uma "composição à vista de gravura", de "trechos narrativos" ou ainda de "cartas".

A pouca importância atribuída à prática da escrita em sala de aula resiste até a primeira metade do século XX. A escola não concebe o ato de escrever para além do domínio do código linguístico, e os professores acreditam que tal domínio é adquirido através de uma relação de espelhamento. Sob essa ótica, basta apenas que o aluno tome "bons textos" como referência de modo a fazer as qualidades gramaticas e estéticas deles refletirem-se em suas composições. Nesse sentido, o saber escrever é visto como algo resultante de práticas de imitação. Sobre essa fase do "trabalho" com a escrita, Bunzen (in BUNZEN; MENDONÇA, 2006, p. 141-142) afirma que

Durante um longo período, que vai desde o final do século XVIII até meados do século XX, percebemos um destaque muito maior para o ensino das regras gramaticais $\mathrm{e}$ da leitura - entendida como uma prática de decodificação e memorização de textos literários - do que do escrever. $\mathrm{O}$ "ensino" da composio, como eram chamados os textos escritos pelos alunos, estava reservado praticamente para as últimas séries do chamado ensino secundário, nas disciplinas retórica, poética e literatura nacional. Nessa época, fazer composição significava escrever a partir de figuras ou títulos dados, tendo como base os textos-modelo apresentados pelo professor.

Entre os anos de 1960 e 1970, embora ainda não se tenha uma preocupação com um efetivo trabalho de ensino da escrita, o contexto social vigente começa a requerer novos direcionamentos pedagógicos. $\mathrm{O}$ acesso à escola pública torna-se mais amplo. Ela deixa de ser um espaço restrito a uma classe socioeconomicamente privilegiada e passa a receber crianças oriundas das camadas mais populares. Os meios de comunicação em massa também se ampliam, atingindo uma maior parcela da população. 
No cenário político, dá-se a implantação do Regime Militar, e o país é : levado à expectativa de um acelerado desenvolvimento econômico e : tecnológico.

Dentro desse contexto social, o ensino de português precisa ser redirecionado a fim de dar conta das novas demandas; por conseguinte, a escrita em sala de aula ganha outros encaminhamentos. Em 1971, com a Lei n ${ }^{\mathrm{a}} 5692$ de Diretrizes e Bases da Educação, a disciplina de português é transformada em Comunicação e Expressão e Comunicação em Lingua Portuguesa nas séries iniciais e finais do $1^{\underline{a}}$ grau, respectivamente; o rótulo de Lingua Portuguesa e Literatura fica reservado apenas ao $2^{\text {a }}$ grau. Assim, o foco é deslocado para a comunicação. Como bem ressalta Bunzen (op. cit., p. 144), "o saber sobre a língua "deixa", em certo sentido, de ser o enfoque principal, dando vez à compreensão e ao estudo dos cdigos comunicacionais." Nesse momento, o ensino da língua portuguesa passa a ser fortemente influenciado pela teoria da comunicação do Roman Jakobson, para quem o ato de comunicação constitui-se da seguinte maneira:

O REMETENTE envia uma MENSAGEM AO DESTINATÁRIO. Para ser eficaz, a mensagem requer um CONTEXTO a que se refere (ou "referente", em outra nomenclatura algo ambígua), apreensível pelo destinatário, e que seja verbal ou suscetível de verbalização; um CÓDIGO total ou parcialmente comum ao remetente e ao destinatário (ou, em outras palavras, ao codificador e ao decodificador da mensagem); e, finalmente, um CONTACTO, um canal físico e uma conexão psicológica entre o remetente e o destinatário, que os capacite a ambos a entrarem e permanecerem em comunicação. (JAKOBSON, 1969, p. 123)

Não mais é prioridade saber as regras da gramática da língua nem redigir de acordo com padrões estéticos de textos de referência. É a capacidade de comunicar-se, sob a perspectiva da dicotomia emissor/ receptor, que deve ser priorizada. $\mathrm{O}$ escrever ganha fins utilitários. $\mathrm{Na}$ condição de remetente ou de destinatário, o aluno precisa dominar códigos 
como mecanismos de comunicação.

Contudo, não há uma mudança quanto à visão de língua. A visão sistêmica continua prevalecendo. É bem verdade que o olhar se volta para a comunicação, mas também é verdade que se trata de uma concepção de comunicação ainda assentada sobre as bases de um projeto estruturalista ${ }^{2}$. Segundo Geraldi (in GERALDI, 2005, p. 41), "essa concepção está ligada à teoria da comunicação e vê a língua como código (conjunto de signos que se combinam segundo regras) capaz de transmitir ao receptor certa mensagem." Apesar de a gramática não ser mais o foco do ensino, ela continua sendo rigorosamente cobrada na correção das composições dos alunos. Beth Marcuschi (Idem., p. 66) diz que

Do início do século XX até o final dos anos 1980, as aulas direcionadas para o ensino da língua portuguesa dedicavam, em maior ou menor grau, parte expressiva do seu tempo a questões voltadas para a escrita correta, compreendida como a escrita que primava pela observância das regras da gramática normativa e da ortografia.

No entanto, por mais paradoxal que isto possa parecer: mesmo ainda não sendo dedicada uma devida atenção à prática escolar da escrita, é nesse período, da forte influência da teoria da comunicação e, sobretudo, do predomínio da visão de língua enquanto código, que se inicia uma fase de maior valorização da competência de produção de textos dos alunos. Em 1978, o Decreto Federal nª 79.298 torna obrigatória a prova de redação nos vestibulares. A medida dá-se em resposta às críticas ao modelo das provas com apenas questões de múltipla-escolha e à, cada vez mais evidente, pouca habilidade dos alunos com a escrita.

Somente a partir do final dos anos 80 , em decorrência dos avanços ocorridos no campo dos estudos da língua/linguagem, é que à escola se apresentam uma nova concepção de língua e de texto e, consequentemente, uma nova concepção de ensino da escrita com uma redefinição do papel da gramática dentro dele. A partir de agora, a teoria da comunicação passa a dar lugar a uma perspectiva sociointeracionista. Começa a haver um

2 Trata-se de uma alusão ao estruturalismo linguístico, paradigma dentro do qual a teoria da comunicação do Jakobson é moldada. 
apelo para que a escola conceba a língua como prática de interação social, e não mais como um mero sistema de códigos. O texto precisa ser tomado : como entidade discursiva, de cuja natureza, a além da gramática da língua, participam aspectos pragmáticos e cognitivos. Torna-se, então, necessário que o aluno deixe de ser visto passivamente como emissor e receptor de mensagens e seja compreendido como um sujeito que age socialmente por meio da linguagem. Nesse sentido, carece que ele abandone a condição de escritor de redação escolar e ocupe a qualidade de produtor de textos. Para tanto, não cabe mais à escola apenas exigir redações. Faz-se necessário que ela crie "um espaço" no qual a prática da escrita seja, de fato, ensinada, ou melhor: no qual o ensino da escrita seja admitido como produção textual.

\section{O ensino da escrita como produção textual}

As duas últimas décadas representam um período de significativas transformações no tocante à forma como as práticas da escrita são compreendidas no âmbito escolar, mesmo que muitos casos de abordagens tradicionais ainda hoje possam ser atestados. Silva (2011, p. 245-246) diz que

De um ensino de escrita enfatizando-se à estrutura dos textos, passou-se, na última década do século XX e nos primeiros anos do século XXI, a valorizar um ensino de escrita em contexto de interação e suas condições de produção e a aprendizagem de gêneros em sua esfera de circulação.

Por trás dessa valorização da escrita contextualizada, funcional, está outra maneira de ver tanto a língua quanto o texto. A escola começa a assumir uma perspectiva sociointeracionista de língua, sob a qual o ensino da escrita passa a ser admitido como produção textual, e o texto não mais é visto como um mero produto descontextualizado.

Admitir o ensino da escrita como produção textual significa, acima de tudo, conferir ao ato de escrever um valor utilitário bem diferente daquele dos anos 60 e 70. Um texto não consiste num conjunto de códigos sistematicamente reunidos para apenas fazer transmitir uma mensagem de 
: um indivíduo a outro. $\mathrm{Na}$ vida social, somos chamados a agir por meio : da escrita. Os textos são entidades discursivas através das quais assumimos nossa condição de sujeitos socialmente situados. Quando escrevemos, buscamos ver realizados determinados propósitos motivadores de nossa escrita. Objetivamos sempre bem mais do que a simples decodificação dos códigos utilizados. Por textos, dão-se as relações humanas a partir de relações discursivas. É nessa segunda forma relação que a primeira se define. Toda prática de escrita, ou produção textual, consiste num evento de discurso cujos sujeitos envolvidos usam a língua para defender seus interesses numa tentativa de "controle" do outro. Daí que o valor da escrita só existe no valor sociointerativo da língua. Tal perspectiva é a que aparece na base das orientações dos PCNEM. De acordo com o documento,

O aluno deve ser considerado como produtor de textos, aquele que pode ser entendido pelos textos que produz e que o constituem como ser humano. O texto só existe na sociedade e é produto de uma história social e cultural, único em cada contexto, porque marca o diálogo entre os interlocutores que o produzem e entre os outros textos que o compõem (PCNEM, 2000, p. 18). (grifo dado)

Sendo assim, no ensino da escrita como produção textual, não faz sentido a existência de um receptor de mensagens. Aquele para quem escrevemos não é alguém que passivamente recebe nossos textos. Ele interfere, direta ou indiretamente, nas nossas decisões discursivas. Apesar de, diferentemente da fala, a escrita, normalmente, não ocorrer com a presença simultânea do locutor e do interlocutor, a imagem que temos desse último é suficiente para determinar grande parte de nossas escolhas na organização textual. Do mesmo modo que, na fala, não dizemos qualquer coisa de qualquer jeito para qualquer pessoa, na escrita, também não o fazemos. É fundamental que saibamos de quem se trata o nosso interlocutor. É a existência dele, mesmo in absentia, que norteia o que deve ser dito e, sobretudo, como pode ser dito.

Esse é um dos principais pontos de divergência entre a prática da escrita concebida enquanto produção textual e 
a tradicional prática da redação escolar. $\mathrm{Na}$ escrita sob a perspectiva da teoria da comunicação, o aluno sabe que os textos sempre são direcionados a alguém, isto é, eles têm um receptor/destinatário, porém, na hora de produzilos, a figura do receptor sequer hipoteticamente aparece. $\mathrm{O}$ apagamento do interlocutor não se dá por acaso. Como é uma prática de escrita desprovida de função social, ele não é visto como necessário. $\mathrm{O}$ espaço vazio resultante de sua ausência é "ocupado" pelo professor. Como bem afirma Marinho (in DELL'ISOLA; MENDES, 1997, p. 88), A prática de produção de textos, no entanto, não deve ser confundida com o exercício de redação. A redação é uma atividade, já presente nas aulas de português há muito tempo, em que os alunos devem escrever um texto, para o professor, no momento por ele proposto, sobre temas propostos também por ele, em que não haviam pensado antes, e ainda para que sejam julgados, testados. Ou seja, o exercício da redação se dá numa situação artificial e forçada de emprego da língua, constituindo-se numa atividade de produção de textos para a escola, para o professor.

Embora o professor fique no lugar esvaziado pelo apagamento do interlocutor, ele jamais cumpre tal papel. $\mathrm{O}$ aluno não vê na figura do professor um sujeito com o qual esteja estabelecendo um ato de interação verbal. O professor é percebido como uma espécie de fiscal, e, nesse sentido, ele ocupa a posição de receptor, e não a de interlocutor. Cabe-lhe a função de apenas decodificar a escrita do aluno, verificando a pertinência das ideias apresentadas ao tema proposto e, principalmente, o respeito às regras da gramática normativa. Outra implicação da ausência do interlocutor está no fato de que, por não se saber para quem vai o texto, não há como lhe determinar qualquer forma de registro, e disso decorre que as práticas de redação acabaram por fixar tanto um modelo engessado de texto, como também um estilo padrão de língua a nele ser usado.

Fora da escola, salvo alguns concursos, os vestibulares e o ENEM, a redação não está presente em nenhuma atividade de uso real da língua. 
Nas suas interações sociais, os sujeitos não se comunicam através dela. A : artificialidade inerente às práticas escolares da escrita, das quais o modelo redação é originário, anula a possibilidade de existir qualquer relevância social para o seu uso. $\mathrm{Na}$ vida em sociedade, os contextos de realização da língua são bastante diversificados. Cada situação comunicativa impõe aos interlocutores necessidades discursivas particulares e determinantes do que é ou não cabível no processo de interação. Não é possível que sempre nos comuniquemos do mesmo jeito. Nos usos reais que fazemos da língua, estão presentes os mais diversos gêneros textuais. Diferentemente do que acontece na escola, a vida fora dela exige que escrevamos bilhetes, currículos, relatórios, convites, cartas, torpedos, e-mails e inúmeros outros gêneros textuais. Como diz Marcuschi (in DIONISIO; MACHADO; BEZERRA, 2002, p. 19),

(...) os gêneros textuais são fenômenos históricos, profundamente vinculados à vida cultural e social. Fruto de trabalho coletivo, os gêneros contribuem para ordenar e estabilizar as atividades comunicativas do dia-a-dia. São entidades sócio-discursivas e formas de ação social incontornáveis em qualquer situação comunicativa.

Uma vez que servem à ordenação e à estabilidade das atividades comunicativas do dia-a-dia, não há evento sociointerativo que não seja por meio deles. Ora, se os sujeitos não podem dizer o que querem de qualquer maneira, precisam sempre acionar os gêneros como parâmetros para as decisões discursivas. Assim, na produção de textos, não existe, como ocorre na redação, padrões únicos de texto e de estilo de língua a serem seguidos. O que há, sobre todos os aspectos, é a ampla heterogeneidade constitutiva da língua. A própria natureza de cada evento sociointerativo já se encontra vinculada à necessidade social da existência de cada gênero. $\mathrm{Na}$ observância das particularidades do contexto de comunicação e, principalmente, dos propósitos discursivos a serem nele atingidos, é que o modelo textual a ser seguido é acionado. A partir daí, decorrem não só escolha do estilo de língua apropriado, como também as decisões a respeito de todos os outros aspectos linguísticos e não-linguísticos envolvidos na prática da escrita. $\mathrm{O}$ 
ensino de produção de textos não privilegia formas únicas de gênero e tipo textuais nem de registro linguístico em detrimento das demais. Enquanto : a prática da redação centra-se num gênero padrão - a própria redação escolar -, no tipo textual dissertativo e na norma-padrão como registro linguístico, a produção textual privilegia o estatuto pragmático do texto. Nesse sentido, nada é fixo. Tudo depende do que se dir, de como se dir, de para quem se dir e de onde e quando se dir.

Desse modo, sob uma perspectiva pragmática, torna-se condição sine qua non do trabalho com a escrita a valorização das características do contexto em que se dá o ato de escrever. Além da imprescindível consideração da existência de interlocutores, é também fundamental que o exercício escolar da escrita vise à competência textual da produção de gêneros diversos requeridos pelas mais variadas situações de uso da língua. Cabral (in FIGUEIREDO-GOMES; OLIVEIRA; ARAÚJO, 2011, p. 342) afirma que

(...) centralizar o processo ensino-aprendizagem da linguagem na compreensão e produção de um número crescente de gêneros pode trazer mudanças significativas. O trabalho com a língua ganha autenticidade, os textos produzidos deixam de ser textos que servem apenas para a escola, desarticulados da vida além dos seus muros. Passam a ser textos com funcionalidade social, que proporcionam aos seus leitores e produtores vivenciar relações mais proficientes, mais cidadãs.

Através da produção de gêneros, o aluno é colocado diante de situações-problema de natureza sociodiscursiva. A ele não mais simplesmente se exige que codifique suas ideias sobre uma determinada temática numa sequência dissertativa para, posteriormente, submetê-la à apreciação do professor. Situado numa prática de escrita contextualizada, o aluno é levado a refletir acerca da linguagem. Ele precisa saber que gênero é requerido pela situação de comunicação proposta, quais suas características composicionais - aí se incluem os tipos textuais envolvidos e o registro linguístico adequado -, como tais características formais 
: correlacionam-se com a função sociocomunicativa do gênero e, acima de : tudo, por meio das construções de sentido criadas pelas escolhas efetuadas na organização textual, demonstrar habilidade na mobilização de conhecimentos de mundo com vistas a realizar intenções comunicativas nas relações sociointeracionais. Essa forma de trabalho com a escrita vai ao encontro do que dizem os PCNEM. Para o documento, o uso da língua

(...) depende de se ter conhecimento sobre o dito/escrito (a leitura/análise), a escolha de gêneros e tipos de discurso. Tais escolhas refletem conhecimento e domínio de "contratos" textuais não declarados, mas que estão implícitos. Tais contratos exigem que se fale/escreva desta ou daquela forma, segundo este ou aquele modo/gênero. Disso saem as formas textuais (PCNEM, 2000, p. 22).

Ainda segundo o documento,

A escola não pode garantir o uso da linguagem fora do seu espaço, mas deve garantir tal exercício de uso amplo no seu espaço, como forma de instrumentalizar o aluno para o seu desempenho social. Armá-lo para poder competir em situação de igualdade com aqueles que julgam ter o domínio social da língua (Idem.).

O ensino da escrita como produção textual, na media em que privilegia o estatuto pragmático do texto, demanda também uma redefinição da posição do professor. Ele precisa sair da condição de receptor-corretor, abrindo o espaço à ocupação de um efetivo interlocutor, e assumir a posição de avaliador ${ }^{3}$. Toda a complexidade pragmática constitutiva do ato de escrever pede que o texto seja visto enquanto processo, e não enquanto produto. Até a finalização de uma atividade de escrita, muitas

3 Aqui, é adotada uma concepção formativa de avaliação da escrita, e não somativa. De acordo com Beth Marcuschi (2004, p. 80), na avaliação formativa, "o parâmetro assumido para a avaliação é a posição do indivíduo em função das aprendizagens desejadas e sócio-historicamente ancoradas, em termos dos progressos realizados pelo aprendiz no confronto com suas próprias posições anteriores.” Na segunda forma de avaliação, insere-se perfeitamente a chamada correção, na qual não há uma preocupação com o confronto entre diferentes momentos do processo de aprendizagem. 
são as etapas percorridas. Como já dito, o trabalho de produção textual põe o aluno diante de situações-problema de natureza sociodiscursiva dentro das quais são vários os saberes necessários, e as relações a serem estabelecidas entre eles. De maneira oposta ao que ocorre na prática da redação, a escrita como produção requer do professor o acompanhamento de todo o processo. Seu papel não se esgota no sujeito que indica os temas e recebe textos acabados para fins de correção.

A tarefa de acompanhar, passo a passo, o escrever, embora se mostre bem mais trabalhosa, possibilita que as dificuldades dos alunos sejam gradativamente observadas tanto no geral quanto em casos particulares. Todos eles não apresentam as mesmas dificuldades na hora de redigir. Enquanto um, por exemplo, pode, apesar da boa capacidade argumentativa, ter problemas no tocante à adequação do texto à norma culta da língua, outro pode perfeitamente ser capaz de realizar a referida adequação, mas demonstrar pouca habilidade na escolha das estratégias de argumentação. Assim como as dificuldades nem sempre são as mesmas para todos os alunos, elas nem sempre são as mesmas em todos dos momentos da aprendizagem. Nesse sentido, o acompanhamento também se faz necessário em função da observação do progresso da aprendizagem. Se o professor não acompanha o processo, a ele não é possível intervir direta e sistematicamente no problema. Oliveira (2010, p. 164) afirma que

Não há nada inerentemente errado no ato de apenas corrigir um texto. Essa prática é muito comum em empresas de grande porte. Antes de enviarem um documento para alguém ou de publicarem um texto em jornais e revistas, as empresas designam um funcionário, às vezes com a função exclusiva de revisor textual, a tarefa de buscar erros e corrigi-los. Chama-se essa prática de revisão textual. Ela também tem um lugar importante no universo acadêmico, mas, na sala de aula, não ajuda os alunos em nada.

O trabalho de avaliação deve ser tão processual quanto o ato de escrever. Diferentemente do corretor, o professor avaliador, por conceber a escrita como uma ação gradual, adota a prática de reescrita como uma 
importante ferramenta de ensino-aprendizagem. O texto não pode ser : apenas cobrado. Ele deve ser efetivamente ensinado e, para tanto, precisa ser reescrito. A fala é adquirida, ou seja, é uma competência natural dos falantes nativos de qualquer língua, mas o mesmo não ocorre com a competência textual. Só se escreve, se se aprende. Na prática da redação, o fato de o professor estar presente em apenas dois momentos: o inicial, da indicação do tema, e o final, da correção, torna-se menos trabalhoso porque o exclui de todas as outras etapas do processo, e são essas etapas entre o início e o fim que, realmente, correspondem ao fazer da escrita. Não há, sem o trabalho de reescrita, como o professor sair das extremidades para fazer-se presente na zona intermediária do processo, restando-lhe apenas a condição de receptor-corretor de textos-produto. Contudo, quando a escola trata o texto como produto, ela, em certo sentido, nega aos alunos o aprendizado da escrita, desobrigando-se do cumprimento do seu papel social.

Por ser mais ampla, abarcando todo o processo, a avaliação não se limita a indicar os chamados erros. Nela, a produção textual é observada qualitativamente. Há uma preocupação com a valorização dos saberes já assimilados pelos alunos e com a busca de estratégias de ensinoaprendizagem direcionadas ao que ainda precisa ser aprendido. $\mathrm{O}$ foco da avaliação volta-se para as competências e habilidades necessárias à escrita de textos funcionalmente relevantes nas interações sociocomunicativas.

Com o olhar voltado para as competências e habilidades, o professor, desde o início da atividade de produção de texto, necessita dar atenção não somente às exigências contextuais, como também às de ordem cognitiva do ato de escrever. A produção textual, além de precisar ser devidamente inserida numa situação social de comunicação, ela exige que o aluno possua os conhecimentos de mundo indispensáveis às ações discursivas dentro da situação-problema que a ele se apresenta. Não adianta, por exemplo, que saiba de quem se trata o interlocutor, que gênero e tipo textuais devem ser acionados, se não tiver um lugar discursivo de onde enunciar. Em qualquer contexto de interação, é imprescindível que tenhamos o que dizer. O domínio linguístico-textual per si não garante a produção de um texto. Mesmo que o sujeito seja um escritor proficiente, não é capaz 
de redigir, caso não tenha conhecimento acerca do assunto. Como bem ressalta Antunes (2003, p. 45),

A atividade da escrita é, então, uma atividade interativa de expressão, (ex-, "para fora”), de manifestação verbal das idéias, informações, intenções, crenças ou dos sentimentos que queremos partilhar com alguém, para, de algum modo, interagir com ele. Ter o que dizer é, portanto, uma condição prévia para o êxito da atividade de escrever.

Daí que, de modo diferente do que normalmente acontece com a redação escolar, a prática da escrita necessita ser ancorada numa introdução à temática em questão.

No ensino do texto como produção, nada deve dar-se aleatoriamente. Toda a contextualização é pensada em função de um ensino sistemático da escrita, posto que, somente assim, é à escola possível buscar, através do trabalho pautado nos usos sociais da língua, o desenvolvimento da competência textual dos sujeitos, possibilitando-lhes o amplo domínio da escrita, domínio esse que é condição essencial ao pleno exercício da cidadania.

\section{A escrita no enem}

Surgido em 1998, o ENEM, assim como os PCEM, inserese no bojo das reformas sofridas pelo Ensino Médio a partir de 1996, com a publicação da nova LDB. O exame adota como princípio a indissociabilidade entre educação e cidadania, priorizando a relevância prática e social do conhecimento. Ele é não-obrigatório e, diferentemente da maioria dos vestibulares, não tem como objetivo avaliar a quantidade de conhecimento armazenado pelo aluno. Destina-se à avaliação do desempenho dos alunos egressos da educação básica na aplicação dos conteúdos disciplinares à resolução de problemas do dia-a-dia. Segundo Castro e Tiezzi (in SCHWARTZMAN, 2005, p. 131),

O que está presente na concepção do Enem é a importância de uma educação com conteúdos analiticamente mais ricos, voltados para o desenvolvimento do raciocínio e a 
capacidade de aprender a aprender, buscando a eliminação paulatina dos currículos gigantescos e permitindo que as escolas do ensino médio concentrem-se no que é importante ensinar. Neste sentido, a escola deve assegurar aos alunos o desenvolvimento das estruturas mais gerais das linguagens, das ciências, das artes e da filosofia, numa dinâmica de ensino que permita ao jovem mobilizar esses conhecimentos tradicionais na busca de soluções criativas para problemas cotidianos devidamente contextualizados.

Sob essa perspectiva da relevância social do conhecimento, é que o ENEM também se propõe a avaliar a escrita. A avaliação é pautada numa matriz composta por 5 competências. A $1^{\circ}$ diz respeito à normapadrão da língua. Nela, é observado o domínio do português padrão. A $2^{\circ}$ está relacionada à compreensão da proposta apresenta na prova, sendo verificado o respeito ao tema e ao tipo textual solicitados. É observada ainda a aplicação de conhecimentos de diferentes campos do saber na abordagem do tema. A $3^{\circ}$ direciona-se à capacidade de argumentação. Aqui, são analisados os argumentos selecionados quanto à pertinência deles em relação à temática e ao ponto de vista assumido. A $4^{\circ}$ liga-se ao conhecimento dos mecanismos linguísticos de articulação textual. Nesse ponto, são verificadas as estratégias de organização textual em função da construção da argumentação. A $5^{\circ}$ tem a ver com a capacidade de elaboração e apresentação de uma proposta de intervenção na problemática trazida pelo tema. Exceto a $2^{\circ}$, todas as outras são avaliadas através de níveis de habilidade de 0 a 5 . O nível 0 não pode ser atribuído à $2^{\circ}$ competência porque já se caracteriza como fuga ao tema.

$\mathrm{Na}$ composição da matriz, é perceptível a existência de uma preocupação com a adoção de critérios de avaliação voltados para a funcionalidade da escrita, por meio dos quais se busca a criação de um sistema avaliativo em consonância com a perspectiva do valor social do conhecimento. A observação do texto vai além de suas características formais. Há a intenção de que os aspectos linguístico-textuais sejam considerados em função da construção de sentidos. $\mathrm{Na} 4^{\circ}$ competência, por exemplo, os mecanismos de coesão não são vistos como simples emendas das frases 
do texto. Mais do que as conexões em si, está em jogo a maneira como o aluno é capaz de realizá-las, pondo-as a serviço da sua argumentação. $\mathrm{O}$ : cuidado com o valor discursivo do texto também é muito evidente na $2^{\circ}$, na $3^{\circ}$ e na $5^{\circ}$ competência. A $2^{\circ}$, na medida em que preza pela capacidade de relacionar conhecimentos de diferentes áreas, vai ao encontro da $3^{\circ}$. Em ambas, é avaliado quão competente o aluno se mostra na utilização dos saberes adquiridos para a construção de uma argumentatividade com sólida sustentação do seu posicionamento. A inserção da $5^{\circ}$ competência na matriz apresenta-se diretamente vinculada ao projeto de uma educação com fins utilitários. A temática da proposta coloca o aluno diante de uma situação-problema que exige dele a mobilização de seus conhecimentos na tentativa de formular uma solução exequível e coerente com a linha argumentativa assumida.

Todavia, apesar do anseio por uma valorização funcional da escrita presente na base da matriz de competências, a avaliação não contempla a funcionalidade do texto sob uma perspectiva mais ampla. Ocorre, num certo sentido, uma ruptura no sistema avaliativo. Ao mesmo tempo em que, por um lado, é perceptível a preocupação com o valor prático da escrita, por outro, pode também ser observado a sua parca consideração. O sistema avaliativo deve ser visto em sua totalidade. Ele não deve limitarse à aplicação da matriz na análise dos textos pelo avaliador. $\mathrm{O}$ processo de avaliação começa já na realização do exame. Nesse sentido, para que haja uma apreciação efetivamente alicerçada na visão de texto como prática social, torna-se indispensável que a proposta apresentada esteja, de fato, alinhada com tal visão. Inclusive, essa é a concepção que aparece declaradamente adotada no Manual de Capacitação para a Avaliação das Redações do ENEM 2012. Ele diz que

A avaliação dos textos, no ENEM, tem por objetivo verificar competências linguísticas na dimensão textual. Isso implica considerar o desempenho linguístico do participante quanto às habilidades de demonstrar conhecimento dos mecanismos linguísticos necessários para a seleção, organização e interpretação de informações, estruturandoas em um texto do tipo dissertativo-argumentativo, no qual 
se constituem entidades significativas: pela tessitura textual percebe-se a intrínseca relação entre linguagem, mundo e práticas sociais. (MANUAL DE CAPACITAÇÃO DO ENEM, 2012, p. 9)

É inegável que, pela própria natureza do exame, não é possível nem necessário que todas as características da escrita como produção textual se façam presentes. Não cabem coisas como, por exemplo, a reescrita do texto. O momento de a prática da escrita ser treinada corresponde ao período de escolarização. O papel do ENEM é somente avaliá-la. Contudo, uma vez que assume uma visão de texto fincada na relação entre linguagem e mundo e, sobretudo, como prática social, ele precisa criar uma proposta de produção textual que melhor atenda às concepções assumidas. Se os alunos, durante os anos de escola, devem ser treinados quanto à prática da escrita inserida em situações reais de uso da língua, eles também devem ser avaliados sob as mesmas condições, haja vista a articulação entre ENEM e PCNEM. Castro e Tiezzi (Idem., p. 132) afirmam que

O Enem segue as orientações da reforma do ensino médio e contempla as diretrizes dos Parâmetros Curriculares do Ensino Médio, ao demonstrar, por meio de uma prova, como é possível trabalhar os diferentes conteúdos numa perspectiva transdisciplinar, privilegiando a aprendizagem a partir da resolução de problemas de temáticas presentes no contexto pessoal dos alunos e social da escola e do meio onde estão inseridos.

A despeito dos avanços verificados na matriz de avaliação, ainda subjaz à prova de redação do ENEM uma concepção tradicional de prática da escrita. Tomemos em análise a proposta de $2012^{4}$ :

4 A proposta analisada, embora seja de 2012, continua a ser representativa do modelo aqui discutido, uma vez que o ENEM, até a sua última edição (2016), mantém o mesmo padrão de proposta de redação. 


\section{PROPOSTA DE REDAÇÃO}

A partir da leitura dos textos motivadores seguintes e com base nos conhecimentos construídos ao longo de sua formaçāo, redija texto dissertativo-argumentativo em norma padrão da língua portuguesa sobre o tema O MOVIMENTO IMIGRATÓRIO PARA O BRASIL NO SÉCULO XXI, apresentando proposta de intervenção, que respeite os direitos humanos. Selecione, organize e relacione, de forma coerente e coesa, argumentos e fatos para defesa de seu ponto de vista.

Ao desembarcarno Brasil, os imigrantes trouxeram muito mais do que o anseio de refazer suas vidas trabalhando nas lavouras de café e no início da indústria paulista. Nos séculos $X I X$ eXX, os representantes de mais de 70 nacionalidades e etnias chegaram com o sonho de "fazer a América" e acabaram por contribuir expressivamente para a história do pais e para a cultura brasileira. Deles, o Brasil herdou sobrenomes, sotaques, costumes, comidas e vestimentas.

A história da migração humana não deve ser encarada como uma questão relacionada exclusivamente ao passado; há a necessidade de tratar sobre deslocamentos mais recentes.

Acre sofre com invasão de imigrantes do Haiti

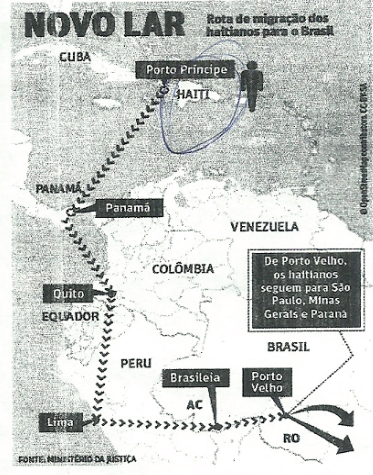

Disponival em: http:///mg1.com. br. Acesso em: 19 jul. 2012

Nos últimos três dias de 2011 , uma leva de 500 haitianos entrou ilegalmente no Brasil pelo Acre, elevando para 1400 a quantidade de imigrantes daquele pais no município de Brasileia (AC). Segundo o secretário-adjunto de Justiça e Direitos Humanos do Acre, José Henrique Corinto, os haitianos ocuparam a praça da cidade. A Defesa Civil do estado enviou galões de água potável e alimentos, mas ainda não providenciou abrigo.

A imigração ocorre porque o Haiti ainda não se recuperou dos estragos causados pelo terremoto de janeiro de 2010. O primeiro grande grupo de haitianos chegou a Brasileia no dia 14 de janeiro de 2011. Desde então, a entrada ilegal continua, mas eles não são expulsos: obtêm visto humanitário e conseguem tirar carteira de trabalho e CPF para morar e trabalhar no Brasil.

Segundo Corinto, ao contrário do que se imagina, não são haitianos miseráveis que buscam o Brasil para viver, mas pessoas da classe média do Haiti e profissionais qualificados, como engenheiros, professores, advogados, pedreiros, mestres de obras e carpinteiros. Porém, a maioria chega sem dinheiro.

Os brasileiros sempre criticaram a forma como os países europeus tratavam os imigrantes. Agora, chegou a nossa vez afirma Corinto.

Trilha da Costura

Os imigrantes bolivianos, pelo último censo, săo mais de 3 milhões, com populaçăo de aproximadamente 9,119 milhões de pessoas. A Bolivia em termos de IDH ocupa a posição de $114^{\circ}$ de acordo com os parâmetros estabelecidos pela ONU. O país está no centro da América do Sul e é o mais pobre, sendo $70 \%$ da população considerada miserável. Os principais países para onde os bolivianos imigrantes dirigem-se são: Argentina, Brasil, Espanha e Estados Unidos.

Assim sendo, este é o quadro social em que se encontra a maioria da população da Bolivia, estes dados já demonstram que as motivações do fluxo de imigração não são políticas, mas econômicas. Como a maioria da população tem baixa qualificação, os trabalhos artesanais, culturais, de campo e de costura são os de mais fácil acesso. OLIVEIRA, R.T. Disponivel sm: htip////wmw.ipea.gov.br. Acesso em: 19 jul. 2012 (adaptado)

INSTRUÇÕES:

- O rascunho da redação deve ser feito no espaço apropriado.

- O texto definitivo deve ser escrito à tinta, na folha própria, em até 30 linhas.

- A redação com até 7 (sete) linhas escritas será considerada "insuficiente" e receberá nota zero.

- A redação que fugir ao tema ou que não atender ao tipo dissertativo-argumentativo receberá nota zero.

- A redação que apresentar proposta de intervenção que desrespeite os direitos humanos receberá nota zero.

- A redação que apresentar cópia dos textos da Proposta de Redação ou do Caderno de Questões terá o número de linhas copiadas desconsiderado para efeito de correção.

A proposta enquadra-se perfeitamente no paradigma da redação escolar. Como pode ser verificado, é solicitado que o aluno redija um texto dissertativo-argumentativo sobre o tema "O movimento imigratório para o Brasil no século XXI” e, em seguida, são fornecidos alguns textos de apoio. Eles aparecem como forma de situar o aluno diante da temática. Dão uma espécie de suporte cognitivo, na medida em que permitem ao aluno a aquisição de informações prévias, possibilitando que tenha, minimamente, o que dizer. No entanto, a contextualização da proposta se limita ao fornecimento de tais textos. Nada é dito em relação à situação comunicativa em que se deve dar a escrita. 
Não há nenhuma informação acerca da existência dum possível interlocutor. Ao aluno é exigido escrever um texto por meio do qual não interage com ninguém. A única certeza que ele tem é que o texto será lido por professores avaliadores. Assim como ocorre na redação escolar, a figura do interlocutor é apagada. Aqui, é a banca que passa a "ocupar" o lugar esvaziado pelo apagamento dele.

A mobilização dos conhecimentos necessários à escrita não ultrapassa os limites do próprio texto. Uma vez que não há uma imagem como referência de interlocutor, não se faz necessária a realização de escolhas linguístico-textuais orientadas por propósitos sociointerativos. Basta apenas que a escrita siga um modelo já cristalizado. A composição do texto - padrão redação escolar -, o registro linguístico, o tipo textual, a pessoa do discurso, entre tantos outros aspectos, já se encontram predeterminados. $\mathrm{O}$ aluno precisa apenas redigir uma sequência dissertativa-argumentativa dentro da norma-padrão, bem articulada e com bons argumentos, embora, conforme dito anteriormente, nos usos reais da língua, a atividade de escrita exija bem mais que isso.

Tendo em vista a centralidade num padrão único de texto, a avaliação não contempla a diversidade de gêneros nem de tipos textuais. Apesar de, em consonância com as recomendações dos PCNEM, a perspectiva da escrita como produção de textos prezar pela variedade de modelos discursivos, essa variedade não é valorizada pela prova de redação do ENEM. É importante observarmos que a concepção assumida de escrita como prática social se dá à margem de uma proposta de escrita com função social. O modelo textual requerido pela prova do ENEM não circula nas esferas da vida em sociedade. $O$ perfil da proposta não tem como preocupação criar uma situação-problema para o próprio ato de escrever. $\mathrm{O}$ aluno não é desafiado a produzir um texto que atenda às suas necessidades discursivas dentro de um determinado contexto socialmente situado de interação. Daí a situação-problema da prova de redação ficar restrita à apresentação de ideias de intervenção na problemática social trazida pelo tema, quando, na verdade, a própria situação de escrita é que deveria constituir-se como a situação-problema. Afinal de contas, os usos da língua são sempre situações sociais que nos desafiam a resolver problemas de natureza discursiva. 
Portanto, sedo o sistema avaliativo considerado em sua totalidade, a escrita no ENEM patina entre a vigente perspectiva do texto como : produção, assentada na visão sociointeracionista de língua, e a perspectiva do texto como produto, sob a ótica da teoria da comunicação, que perdurou até os anos 80. Enquanto a composição da matriz de competências busca inserir-se dentro da primeira visão, a chamada proposta de redação ainda preserva as características de uma prática de escrita situada dentro da segunda.

\section{CONSIDERAÇÕES FINAIS}

Devido à importância conquistada pelo ENEM desde o seu surgimento, em 1998, até os dias atuais, sobretudo dos últimos quatro anos para cá, quando se transformou na forma de acesso às principais universidades públicas do país, ele passou a ter uma forte influência não só sobre os conteúdos disciplinares selecionados, como também sobre os métodos de ensino adotados pelas escolas do nível médio. Se antes os últimos anos do processo de escolarização acabavam destinados ao preparo para a prova do vestibular, agora o foco volta-se para a prova do ENEM. O êxito no desempenho dos alunos no exame passa a ser uma exigência social, e as escolas são cobradas a darem conta dessa nova demanda.

Diante de tal contexto, na medida em que a prova de redação do ENEM ainda preserva as características de uma prática de escrita desprovida de função social, ela passa a exercer uma pressão contrária sobre a adoção da perspectiva da escrita enquanto produção textual. Apesar das modernas orientações acerca do trabalho com o texto em sala de aula, as escolas ainda se veem obrigadas a, em certa medida, tomar a redação escolar como objeto de ensino. A ruptura existente no sistema avaliativo, permeado por duas concepções divergentes de língua e de texto, leva o próprio sistema a incorrer numa contradição. Embora o ENEM, de maneira articulada com os PCEM, assuma como princípio a indissociabilidade entre conhecimento e cidadania, buscando, na relevância prática e social, a valorização do conhecimento, o exame ainda preza por uma escrita alheia à sua relevância prática e social, indo de encontro às recomendações dos PCEM. 


\section{REFERÊNCIAS BIBLIOGRÁFICAS}

ANTUNES, Irandé. Aula de português: encontro e interação. São Paulo: Parábola, 2003.

BRASIL. (2000). Parâmetros curriculares nacionais: ensino médio. Disponível em: 〈http://portal.mec.gov.br/seb/arquivos/pdf/14_24.pdf>. Acesso em: 19 nov. 2012.

BRASIL. (2012). Manual de capacitação para a avaliação das redações do ENEM 2012.

BUNZEN, Clecio. Da era da composição à era dos gêneros: o ensino de produção de texto no ensino médio. In: BUNZEN, Clecio; MENDONÇA, Márcia. Português no ensino médio e formação do professor. São Paulo: Parábola, 2006.

CABRAL, Marlucia Barros Lopes. Os gêneros do discurso/textuais e o ensino-aprendizagem da linguagem. In: GOMES-FIGUEIREDO, João Bosco; OLIVEIRA, Risoleide Rosa Freire de; ARAÚJO, Silvano Pereira. Práticas linguageiras: literatura e ensino. Mossoró: Edições UERN, 2011.

CASTRO, Maria Helena Guimarães de; TIEZZI, Sérgio. A reforma do ensino médio e a implantação do Enem no Brasil. In: SCHWARTZMAN, S.M.C. Os desafios da educação no Brasil. RJ. Ed. Nova Fronteira, 2005.

GERALDI, João Wanderley. Concepções de linguagem e ensino de português. In: GERALDI, João Wanderley (org.). O texto na sala de aula. São Paulo: Ática, 2005.

JAKOBSON, Roman. Lingüística e comunicação. São Paulo: Cultrix, 1969.

MARCUSCHI, Elizabeth. As categorias de avaliação da produção textual no discurso do professor. Recife: UFPE, Programa de Pós-graduação em Letras, 2004. (Tese de doutoramento).

MARCUSCHI, Elizabeth. Escrevendo na escola para a vida. In: RANGEL, Egon de Oliveira; ROJO, Roxane Helena Rodrigues (coords.). Brasília: MEC, 2010. 
MARCUSCHI, Luiz Antônio. Gêneros textuais: definição e funcionalidade. In: DIONÍSIO, Ângela Paiva; MACHADO, Anna Rachel; BEZERRA, : Maria Auxiliadora (orgs.). Gêneros textuais e ensino. Rio de Janeiro: Lucerna, 2002.

MARINHO, Janice Helena Chaves. A produção de textos escritos. In: DELL'ISOLA, R.; MENDES, E. (orgs.). Reflexões sobre a língua portuguesa ensino e pesquisa. Campinas: Pontes, 1997.

OLIVEIRA, Luciano Amaral. Coisas que todo professor de português precisa saber: a teoria na prática. São Paulo: Parábola, 2010.

SILVA, Williany Miranda. Ensinar a escrever: um dilema e muitas práticas. In: Leia Escola, Campina Grande, PB, v. 10, n. 2, p. 241-266, 2011.

SOARES, Magda. Português na escola: história de uma disciplina curricular. In: BAGNO, Marcos. Lingüística da norma. São Paulo: Loyola, 2002. 